\title{
Pencegahan Osteoporosis dengan Suplementasi Kalsium dan Vitamin D pada Penggunaan Korti- kosteroid Jangka Panjang
}

\author{
*Ayu Setyorini, *IKG Suandi, *I Gst Lanang Sidiartha, **Wayan Bikin Suryawan \\ * Bagian Ilmu Kesehatan Anak, Fakultas Kedokteran Universitas Udayana, RSUP Sanglah Denpasar \\ ** Bagian Ilmu Kesehatan Anak, Fakultas Kedokteran Universitas Udayana, RSUD Wangaya Denpasar
}

\begin{abstract}
Osteoporosis merupakan salah satu efek samping tersering pada penggunaan kortikosteroid jangka panjang, namun masih sedikit mendapat perhatian. Kortikosteroid dapat menginduksi osteoporosis dalam 6-12 bulan pertama pemakaian melalui mekanisme langsung maupun tidak langsung. Osteoporosis harus selalu dipikirkan pada anak yang menggunakan kortikosteroid jangka panjang dengan fraktur setelah trauma minimal atau tanpa trauma, nyeri tulang kronik, dan gambaran radiografi menunjukkan penipisan tulang. Efek samping ini dapat dihindari dengan pembatasan dosis kortikosteroid pada dosis minimal yang masih efektif dan mempertahankan nutrisi yang berperan dalam pembentukan tulang seperti kalsium, vitmin D, protein, dan magnesium. Suplementasi kalsium dan vitamin D memiliki efek moderat terhadap penipisan masa tulang, perlu dipertimbangkan pada penggunaan kortikosteroid jangka panjang. (Sari Pediatri 2009;11(1):32-8).
\end{abstract}

Kata kunci: glucocorticoid-induced osteoporosis, kalsium, vitamin D, metabolisme tulang

K ortikosteroid digunakan pada berbagai penyakit alergi, inflamasi, dan penyakit keganasan, sering digunakan dalam jangka panjang (lebih dari dua minggu). Salah satu efek samping penggunaan jangka panjang adalah kehilangan massa tulang yang menyebabkan osteoporosis. Studi mengenai pencegahan dan terapi osteoporosis pada anak masih sedikit.

\section{Alamat korespondensi}

Dr. Ayu Setyorini, Bag/SMF Ilmu Kesehatan anak FK UNUD/RSUP Sanglah Denpasar. Jln Pulau Nias, Denpasar-Bali. Telp/Fax 0361-244038 atau 0361-257387. E-mail: setyorini_mestika@yahoo.com
Prevalensi fraktur akibat osteoporosis pada penggunaan kortikosteroid jangka panjang sekitar 17\%, namun hanya kurang dari setengah yang mendapat pemeriksaan untuk diagnosis osteoporosis dan kurang dari seperempat yang mendapat pencegahan osteoporosis. Hal ini mencerminkan kurangnya kesadaran dan informasi mengenai kemungkinan osteoporosis pada anak yang mendapatkan kortikosteroid jangka panjang. ${ }^{1-3}$

\section{Proses pembentukan tulang}

Tulang terdiri dari matriks ekstrasel dan sel tulang. Matriks ekstrasel terdiri dari bagian organik dan 
Ayu Setyorini dkk: Pencegahan Osteoporosis dengan Suplementasi $\mathrm{Ca}^{++}$dan Vit D pada Penggunaan Kortikosteroid Jangka Panjang

inorganik. Sekitar 90\%-95\% bagian organik matriks ekstrasel terdiri dari kolagen tipe I, proteoglikan, protein non-kolagen, osteokalsin, osteonektin, osteopondin, trombospondin, faktor pertumbuhan, dan sitokin. Bagian inorganik matriks ekstrasel terutama terdiri dari kalsium hidroksiapatit sebagai tempat cadangan ion kalsium dan fosfat. Sel tulang terdiri dari tiga jenis yaitu osteoblast, osteosit, dan osteoklast. Osteoblast bertanggung jawab atas pembentukan tulang, mineralisasi, dan ekspresi reseptor hormon paratiroid. Osteoklast adalah sel tulang multinuklear yang berasal dari prekursor hematopoietik monositmakrofag yang merupakan fusi dari beberapa sel mononuklear dengan tepi tidak rata dan mempunyai enzim lisosom dalam sitoplasma. Sedangkan osteosit adalah sel tulang terbanyak, berbentuk pipih kecil dan terdapat dalam matriks tulang. Antara osteosit satu dengan yang lain saling berhubungan melalui jaringan kanalikuli. Osteosit akan mengalami apoptosis atau fagositosis selama resorpsi osteoklast. Osteosit juga merupakan reseptor mekanik yang mengubah stimulasi mekanik menjadi sinyal yang menginduksi remodelling tulang agar searah stimulasi. ${ }^{4}$ Kepadatan tulang ditentukan oleh keseimbangan dinamik antara proses pembentukan dan resorpsi tulang. Bila pertumbuhan linear dan volume masa tulang maksimal telah tercapai, proses remodelling bertujuan untuk mempertahankan masa tulang. ${ }^{5}$ Remodelling tulang dipengaruhi oleh estrogen, androgen, vitamin D, hormon paratiroid, tumor necrosis factor (TNF), dan insulin like growth factor I dan II, nutrisi, konsumsi kalsium, dan aktivitas fisik. $^{6}$

\section{Osteoporosis}

Osteoporosis adalah keadaan kurangnya masa tulang per unit volume dan mikroarsitektur jaringan tulang yang buruk namun bukan disebabkan oleh defek mineralisasi (osteomalasia). Osteoporosis menyebabkan tulang menjadi lebih rapuh sehingga risiko fraktur meningkat baik pada masa kanak maupun kelak di usia dewasa sehingga osteoporosis dikenal sebagai penyakit pediatri dengan konsekuensi geriatri karena $90 \%$ masa tulang terbentuk sebelum usia 20 tahun. ${ }^{6,7}$ Penambahan masa tulang selama masa anak mengikuti tiga fase. Bone mineral density (BMD) meningkat cepat pada tiga tahun pertama kehidupan, melambat saat masa anak, kemudian meningkat lagi selama masa pubertas hingga mencapai 50\% BMD dewasa dan 90\%
$B M D$ dewasa pada usia 20 tahun. Tidak berlebihan bila kesehatan tulang selama masa anak dan pubertas adalah dasar kesehatan tulang seumur hidup manusia. ${ }^{8,9}$

Terdapat dua jenis osteoporosis pada anak, primer dan sekunder. Osteoporosis primer terjadi akibat defek intrinksik skelet seperti pada osteoporosis juvenil idiopatik dan penyakit jaringan ikat herediter. Osteoporosis sekunder terjadi akibat penyakit lain seperti penyakit neuromuskular (palsi serebral, duchenne muscular distrophy, immobilisasi lama), penyakit kronis, endokrin, dan inborn error metabolism atau penggunaan obat-obat tertentu antara lain kortikosteroid jangka panjang, seperti yang akan dibahas dalam makalah ini.

Diagnosis osteoporosis ditegakkan dengan pemeriksaan dual x-ray absorptiometry (DXA). Penilaian dinyatakan dalam $z$-score, yaitu nilai deviasi standar berdasarkan usia dan jenis kelamin. Densitas tulang berdasarkan usia kronologis, dikatakan rendah bila $Z$-score $<-2,0$. Umumnya yang diperiksa adalah densitas tubuh total yang mencerminkan keadaan korteks tulang dan vertebra lumbalis (L1-L4) yang mencerminkan bagian trabekula tulang. ${ }^{10}$

\section{Fungsi dan metabolisme kalsium}

Kalsium adalah kation ekstrasel utama. Peran utama kalsium adalah untuk kontraksi dan eksitasi otot jantung dan otot lainnya, transmisi sinap sistem saraf, agregasi platelet, koagulasi, dan sekresi hormon dan regulator lain yang memerlukan eksositosis. Kadar kalsium normal dalam plasma $8,5-10,4 \mathrm{mg} / \mathrm{dL}, 45 \%$ terikat protein plasma terutama albumin, $10 \%$ terikat dengan dapar anion seperti sitrat dan fosfat. Empat puluh lima persen sisanya ada dalam bentuk ion dan merupakan bentuk aktif. Kadar kalsium dalam cairan ekstrasel 1\% dari keseluruhan total kalsium tubuh sementara kadarnya dalam sel dijaga sekitar 1/10.000 dari kadar ekstrasel. Fungsi utama kalsium intrasel adalah second messenger intraselular untuk mengatur pembelahan sel, kontraktilitas otot, pergerakan sel, dan sekresi. ${ }^{11,12}$

Sumber kalsium utama dan satu-satunya adalah diet antara lain susu dan produknya seperti keju dan yogurt, sayur-sayuran berwarna hijau, ikan dalam kaleng yang lengkap dengan tulangnya seperti sardin, kacang-kacangan, dan makanan jadi yang difortifikasi dengan kalsium seperti jus, dan sereal. Absorbsi kalsium di saluran cerna terjadi di proksimal 
duodenum yang tergantung pada vitamin $\mathrm{D}$ aktif dan bersifat difusi aktif yang memerlukan calsium binding protein $(\mathrm{CaBP})$ atau kalbindin. Efektivitas absorbsi kalsium di usus dipengaruhi oleh asupan kalsium. Semakin rendah kadar kalsium dalam makanan yang dikonsumsi, semakin aktif pula usus melakukan absorbsi. Sembilan puluh sembilan persen kalsium ekstrasel terdapat dalam tulang dalam bentuk hidroksiapatit yang mencerminkan keseimbangan antara proses pembentukan dan resorpsi tulang. ${ }^{7}$ 9-13

Keseimbangan metabolisme kalsium diatur oleh tiga faktor, hormon paratiroid, vitamin $\mathrm{D}$, dan kalsitonin yang dihasilkan oleh kelenjar tiroid. Membran sel kelenjar paratiroid mengandung sensor kalsium yang dapat mendeteksi kadar kalsium darah. Aktivasi reseptor kalsium terjadi bila kadar kalsium darah tinggi, menyebabkan pelepasan fosfolipase A2, asam arakidonat, dan leukotrien. Leukotrien menginhibisi sekresi hormon paratiroid melalui degradasi $90 \%$ granul sekretori yang mengandung bentuk preformed hormon paratiroid. Aktivasi reseptor kalsium tidak akan terjadi bila kadar kalsium darah rendah. Hormon paratiroid bekerja dengan berikatan dengan reseptor membran sel organ target, yaitu reseptor hormon paratiroid 1 di ginjal dan tulang. Hormon paratiroid meningkatkan reabsorbsi kalsium dengan mempermudah pori kalsium di tubulus distal ginjal terbuka. Hormon paratiroid meningkatkan degradasi tulang dengan bekerja pada osteoblast melalui RANKL di tulang. Hormon paratiroid juga menstimulasi hidroksilasi 25-OH-vitamin D3 menjadi bentuk aktifnya (kalsitriol). Efek kalsitonin terhadap kalsium bertentangan dengan efek hormon paratiroid. Kalsitonin menginhibisi aktivitas osteoklast, mengurangi resorpsi tulang, dan meningkatkan ekskresi kalsium melalui ginjal, jadi fungsi kalsitonin menurunkan kadar kalsium darah. ${ }^{4}$

\section{Fungsi dan metabolisme vitamin D}

Sumber vitamin D utama manusia adalah sinar matahari dan diet. Sinar ultraviolet B (290-315 nm) yang diabsorbsi kulit mengubah 7-dehidrokolesterol menjadi previtamin D3 yang tidak stabil dan cepat diubah menjadi vitamin D3 (kolekalsiferol). Vitamin D3 kemudian keluar dari sel kulit, masuk ke pembuluh kapiler kulit, dan diikat oleh vitamin D binding protein $(D B P)$. Vitamin D dalam makanan diabsorbsi di usus halus dan dengan bantuan asam empedu, diubah menjadi vitamin D2 (ergokalsiferol). Vitamin D3 masuk ke pembuluh limfe setelah diabsorbsi untuk kemudian masuk ke sirkulasi dan berikatan dengan $D B P$ dan lipoprotein. Vitamin D3 kemudian dimetabolisme di hati oleh calciol-25-hydroxylase menjadi pre-hormon 25-OH D3 (kalsidiol) yang masuk ke dalam darah dan di sirkulasi berikatan dengan DBP. Bentuk 25-OH D3 memiliki waktu paruh dua minggu dan kadarnya mencerminkan kadar vitamin D secara keseluruhan, kadar normal $15-50 \mathrm{ng} / \mathrm{mL}$. Konsentrasi kurang dari 25 $\mathrm{ng} / \mathrm{mL}$ menyebabkan peningkatan hormon paratiroid dan resorpsi tulang. Pre-hormon 25-OH D3 dilepas dari ikatannya dengan $D B P$ di ginjal, berikatan dengan megalin sel tubulus, masuk ke dalam sel tubulus dan mengalami hidroksilase di mitokondria. Calcidiol-1hydroxylase menghasilkan bentuk aktif vitamin $\mathrm{D}$ yaitu 1,25-dihidroksi D3 (kalsitriol) sedangkan calcidiol24-hydroxylase menghasilkan bentuk tidak aktif yaitu 24,25-dihidroksi vitamin D (24-hidroksikalsidiol). Kalsitriol menjalankan fungsinya dengan berikatan dengan vitamin $D$ receptor $(V D R)$ di usus halus. Kompleks kalsitriol- $V D R$ berikatan lagi dengan retinoic acidX receptor $(R X R)$ di nukleus dan kompleks kalsitriol$V D R-R X R$ ini kemudian berikatan dengan vitamin $D$ responsive element (VDRE) kalsium epitel. ${ }^{15-17}$

Fungsi utama vitamin $\mathrm{D}$ adalah sebagai pengatur keseimbangan kadar kalsium dengan mengatur absorbsi kalsium di usus halus, interaksi dengan hormon paratiroid sehingga mobilisasi kalsium dari tulang meningkat, dan mengurangi ekskresi kalsium melalui ginjal. Bukti nyata efektivitas vitamin D meningkatkan mineralisasi belum terbukti walaupun defisiensi vitamin $\mathrm{D}$ sering menyebabkan defisit nyata mineral tulang. Deposisi mineral tulang normal memerlukan konsentrasi kalsium dan fosfat optimal yang tergantung keadekuatan absorbsi kalsium. Osteoblast adalah satu-satunya komponen sel tulang yang mengandung reseptor kalsitriol. Ikatan kalsitriol dengan osteoblast menginduksi pelepasan osteokalsin, protein yang mengandung residu asam $\gamma$-karboksiglutamat dan IL-1 yang meningkatkan proses resorpsi. Efek vitamin D pada metabolisme kalsium di ginjal adalah sebaliknya, yaitu meningkatkan reabsorbsi kalsium oleh sel tubulus. Defisiensi vitamin D menyebabkan absorbsi dan reabsorbsi kalsium dan fosfat tidak adekuat sehingga terjadi penurunan konsentrasi kalsium plasma. Penurunan konsentrasi kalsium plasma menyebabkan peningkatan sekresi hormon paratiroid yang bertujuan mengembalikan konsentrasi kalsium 
plasma tetapi dengan resorpsi dari tulang. Kadar fosfat sendiri akan tetap di bawah normal karena hormon paratiroid justru akan menyebabkan ekskresi fosfat melalui urin sehingga tidak terjadi mineralisasi tulang baru dan matriks kartilago yang menyebabkan tulang menjadi rapuh. ${ }^{11}$

\section{Pengaruh dan mekanisme kortikosteroid terhadap masa tulang}

Kortikosteroid disekresi oleh zona fasikulata korteks kelenjar adrenal. Fungsi utama menjaga homeostasis, yaitu mempertahankan diri terhadap perubahan lingkungan, antara lain mengatur metabolisme karbohidrat dan protein, keseimbangan cairan dan elektrolit, dan anti inflamasi. ${ }^{17}$ Kortikosteroid mempengaruhi masa tulang melalui beberapa mekanisme seperti tertera pada Gambar 1.

Pengaruh langsung terjadi karena terdapat reseptor glukokortikoid pada osteoblast dan osteoklast yang apabila terinduksi akan menyebabkan penurunan replikasi dan proliferasi osteoblast, memperpendek waktu remodelling, meningkatkan resorpsi osteoklast, dan menurunkan sintesis IGF-1, prostaglandin E (PGE2), dan IGF-binding protein.
Pengaruh tidak langsung adalah mengurangi absorbsi kalsium di saluran cerna dan meningkatan ekskresi kalsium melalui ginjal, hiperparatiroidisme sekunder, dan defisiensi hormon anabolik akibat berkurangnya sintesis hormon gonadal dan adrenal, mengurangi respon sel terhadap hormon dan faktor pertumbuhan, dan mengurangi IGF-binding protein. Hiperkalsiuria sudah terjadi pada hari kelima pemakaian kortikosteroid. Kadar kalsium darah yang rendah menyebabkan peningkatan hormon paratiroid sekunder dan efek hormon tersebut pada tulang sehingga resorpsi tulang meningkat. Mekanisme lain adalah kortikosteroid meningkatkan ekspresi RANK dan menurunkan ekspresi osteoprotegerin. Kortikosteroid juga meningkatkan ekspresi colonystimulating factor-1 (CSF-1) yang bila ada bersama RANK akan menginduksi osteoklastogenesis. Selain itu kortikosteroid mempengaruhi aktivitas proliferasi dan metabolik sel tulang dengan inhibisi ekspresi gen bone morphogenetic protein-2 (BMP-2) sehingga osteoblastogenesis menurun dan meningkatkan apoptosis sehingga lama hidup osteoblast menurun. Jumlah osteosit yang menurun menyebabkan penurunan kualitas tulang sehingga lebih mudah mengalami fraktur. ${ }^{2,3,16,18-21}$

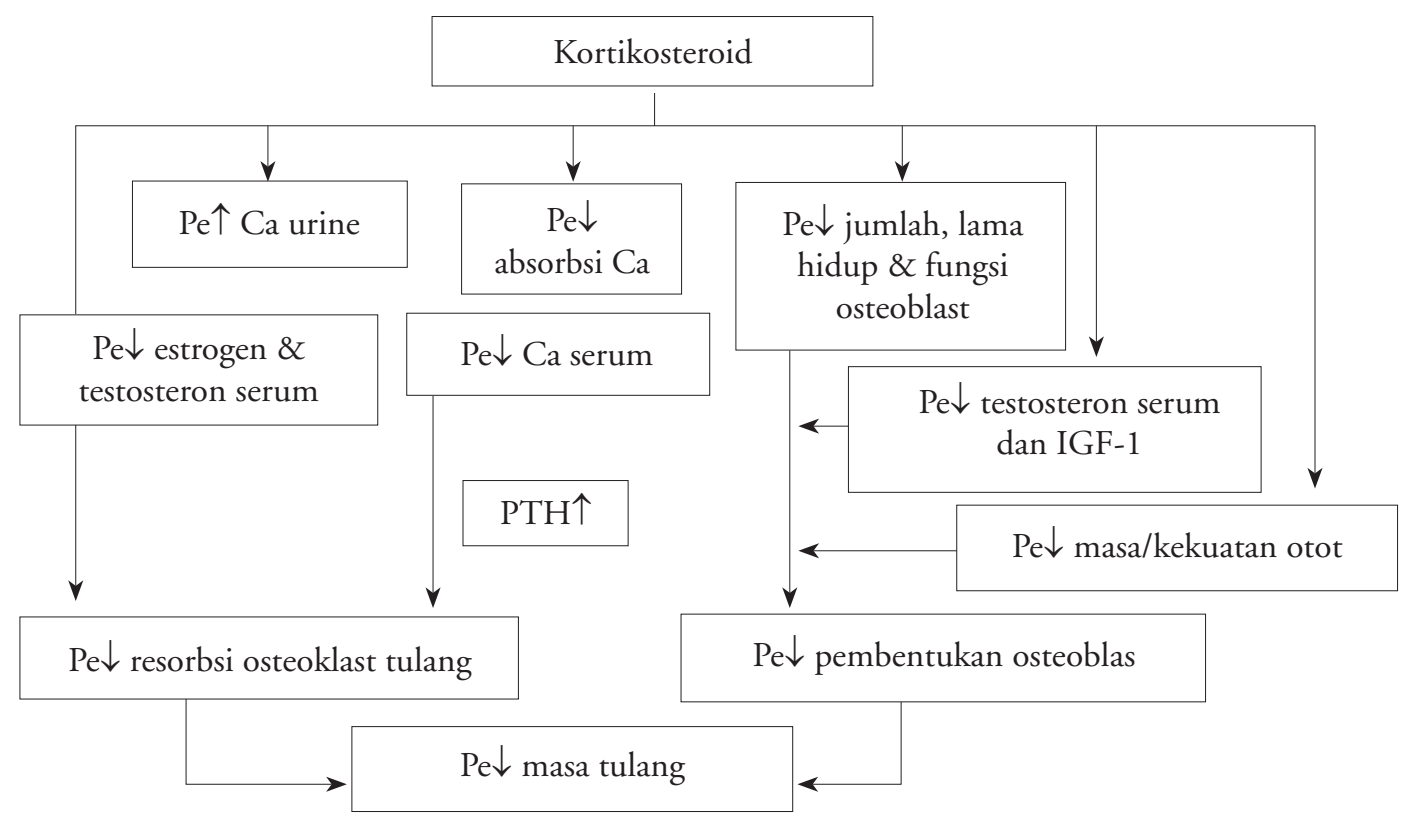

Gambar 1. Mekanisme kehilangan masa tulang pada pemakaian kortikosteroid jangka panjang. Keterangan: $\mathrm{Ca}=\mathrm{kalsium}, \mathrm{IGF}-1=$ insulin growth factor $-1, \mathrm{PTH}=$ hormon paratiroid. Dikutip dari McIlwain $\mathrm{HH}, 2003 .^{2}$ 
Estrogen meningkatkan absorbsi kalsium dan inhibisi sintesis osteoblast. Kortikosteroid menekan aksis hipotalamus-pituitari-adrenal sehingga menekan sekresi hormon gonadotropin dari kelenjar pituitari sehingga kadar estrogen dan testosteron rendah. Akibatnya pembentukan prekursor osteoklast meningkat sehingga jumlah osteoklast meningkat dan resorbsi tulang juga meningkat. Mekanisme ini menyebabkan keterlambatan masa pubertas pada anak yang menggunakan kortikosteroid jangka panjang. ${ }^{2,3,18,22}$

Kehilangan masa tulang terjadi dalam 6-12 bulan setelah pemberian kortikosteroid, terutama di trabekula tulang, tanpa memandang berapa dosis yang diberikan, usia, jenis kelamin, dan penyakit dasar. Pada fase awal, kehilangan masa tulang terjadi dengan cepat (10\%-15\%) akibat resorpsi tulang masif. Pada fase selanjutnya, kehilangan masa tulang terjadi lebih lambat (2\%-5\% per tahun) tetapi progresif akibat gangguan pembentukan tulang. ${ }^{22-5}$ Kortikosteroid menginduksi osteoporosis hingga delapan kali lebih berat bila dibandingkan dengan osteoporosis akibat penyakit dasarnya. ${ }^{2}$

\section{Dosis kortikosteroid}

Kehilangan masa tulang berhubungan dengan dosis kortikosteroid, semakin tinggi dosis kortikosteroid semakin tinggi pula risiko berkurangnya masa tulang dan fraktur. Dosis kortikosteroid terendah yang dilaporkan meningkatkan risiko fraktur adalah prednison 2,5 mg/hari. ${ }^{22-6}$ Kortikosteroid inhalasi tampaknya tidak mempengaruhi densitas tulang. ${ }^{27,28}$

\section{Pencegahan osteoporosis pada kortikosteroid jangka panjang dengan suplementasi kalsium dan vitamin D}

Tujuan tata laksana osteoporosis yang diinduksi oleh kortikosteroid untuk mempertahankan masa tulang yang ada dengan mencegah kehilangan masa tulang lebih lanjut, mengurangi nyeri akibat proses osteoporosis maupun fraktur akibat osteoporosis, mempertahankan atau meningkatkan kekuatan otot, dan menyesuaikan gaya hidup dengan kondisi yang ada. ${ }^{7}$ Tindakan pencegahan untuk mencegah kehilangan massa tulang lebih lanjut harus dilakukan sesuai rekomendasi American College of Rheumatology, yaitu pada anak yang mendapatkan kortikosteroid dalam dosis setara prednison $\geq 5 \mathrm{mg} /$ hari selama lebih dari tiga bulan, terutama pada usia pubertas. ${ }^{2,29}$ Tindakan yang dilakukan antara lain menggunakan dosis kortikosteroid minimal yang masih efektif (prednison $<5 \mathrm{mg} /$ hari atau yang setara menyebabkan kehilangan sedikit masa tulang), nutrisi adekuat untuk perkembangan tulang optimal (protein, fosfat, kalsium, dan vitamin D) dengan menghindari makanan atau minuman yang berpengaruh negatif terhadap mineralisasi tulang (minuman bersoda dan asap rokok), dan menggunakan preparat yang dapat mengurangi hilangnya masa tulang (kalsium, vitamin $\mathrm{D}$, bifosfonat, hormon paratiroid). Beberapa studi telah dilakukan pada anak maupun dewasa untuk menilai efektivitas kalsium dan vitamin D sebagai pencegahan berkurangnya densitas tulang dan mendapatkan hasil yang positif. ${ }^{30-2}$

\section{Dosis suplementasi kalsium dan vitamin D}

Dosis kortikosteroid berpengaruh pada efektivitas kalsium dan vitamin $\mathrm{D}$ dalam pencegahan osteoporosis, semakin rendah dosis, semakin efektif kalsium dan vitamin D. ${ }^{33}$ Kombinasi vitamin D dan kalsium lebih unggul daripada apabila diberikan tersendiri. ${ }^{7}$ Rekomendasi pencegahan dan terapi osteoporosis yang diinduksi kortikosteroid yang direkomendasikan American College of Rheumatology Ad Hoc Committee on Glucocorticoid Induced Osteoporosis adalah sebagai berikut. $^{1,24}$

- Pencegahan dan terapi pada semua pasien. Suplementasi kalsium 500-1000 mg/hari dan vitamin D $800 \mathrm{IU} /$ hari atau vitamin D aktif ( $\alpha$-kalsidiol $1 \mu \mathrm{g} / \mathrm{hari}$ atau kalsitriol $0,5 \mu \mathrm{g} / \mathrm{hari}$ )

- Pencegahan dan terapi pada pasien yang mendapat kortikosteroid dosis moderat-tinggi dengan pemberian kalsium $500-1000 \mathrm{mg} /$ hari dan vitamin $\mathrm{D}$ aktif ( $\alpha$-kalsidiol $1 \mu \mathrm{g} /$ hari atau kalsitriol 0,5 $\mathrm{gg}$ / hari)

- Pada pasien dengan hipogonadal berikan hormon pengganti (estrogen atau testoteron)

Beberapa bentuk preparat kalsium antara lain, ${ }^{31}$ kalsium karbonat merupakan bentuk kalsium paling umum yang mengandung kalsium elemental $40 \%$, karena sulit diabsorbsi maka sebaiknya diberikan bersama makanan atau dikombinasi dengan vitamin $\mathrm{D}$. Kalsium sitrat mengandung kalsium elemental 21\%, absorbsi lebih baik daripada kalsium karbonat, namun harganya lebih mahal. 
Ayu Setyorini dkk: Pencegahan Osteoporosis dengan Suplementasi $\mathrm{Ca}^{++}$dan Vit D pada Penggunaan Kortikosteroid Jangka Panjang

\section{Kesimpulan}

Berkurangnya masa tulang harus selalu dipikirkan pada setiap anak yang menerima kortikosteroid jangka panjang. Tindakan pencegahan dilakukan dengan membatasi dosis efektif dan lama penggunaan kortikosteroid, menjaga nutrisi dan gaya hidup, dan pemberian suplementasi kalsium dan vitamin D.

\section{Daftar pustaka}

1. American College of Rheumatology Ad Hoc Committee on glucocorticoid-induced osteoporosis. recommendations for prevention and treatment of glucocorticoid-induced osteoporosis. Arthritis and Rheumatism 2001;44:1496503.

2. McIlwain HH. Glucocorticoid-induced osteoporosis: pathogenesis, diagnosis and management. Preventive Medicine 2003;36:243-9.

3. Cohen D, Adachi JD. The treatment of glucocorticoidinduced corticosteroid. J Steroid Biochemi and Mol Biol 2004;88:337-49.

4. Molina PE. Parathyroid gland \& Ca \& PO regulation. Dalam: Endocrine Physiology. Edisi ke-1. New York: Lange Medical Books/McGraw-Hill, 2004.h.99-122.

5. Valsamis HA, Arora SK, Labban B, MacFarlane SI. Antiepileptic drugs and bone metabolism. Nutrition and Metabolism 2006;3:36-47.

6. Bianchi ML. How to manage osteoporosis in children. Best practice and research clinical Rheumatology 2005; 19:991-1005.

7. Lacativa PGS, de Farias MLF. Office practice of osteoporosis evaluation. Arq Bras Endocrinol Metab 2006;50:674-84.

8. Allen DB. Inhaled corticosteroid therapy for asthma in preschool children: growth issues. Pediatrics 2002; 109:373-80.

9. Crabtree NJ, Kibirigi MS, Fordham JN, Banks BM. The Relationship between lean body mass and bone mineral content in pediatric helath and disease. Bone 2004; 46:512-60.

10. Damilakis J, Maris TG, Karantanas AH. An update on the assessment of osteoporosis using radiologic techniques. Eur Radiol 2006; 36:440-52.

11. Marcus R. Agents Aaffecting calcification and Bone turnover. Dalam: Wonsiewicz MJ, Morriss JM, penyunting. Goodman and Gilman's the pharmacological basis of therapeutics. Edisi ke-10. New
York: McGraw-Hill Medical Publishing Division; 2001.h.1715-43.

12. Soback D, Marcus D, Bikle D. Metabolic Bone disease. Dalam: Greenspan FS, Gardner DG, penyunting. Basic and clinical endocrinology. Edisi ke-7. New York: Lange Medical Books/McGraw-Hill; 2001.h.295-361.

13. Cheng S, Lyytikainen A, Kroger H, Lamberg-Allardt C. Effects of calcium, dairy product, and vitamin $\mathrm{D}$ supplementation on bona mass accrual and body composition in 10-12 years old girls: a 2 years randomized trial. Am J Clin Nutr 2005;82:1115-26.

14. Bandeira F, Griz L, Dreyer P, Eufrazino C. Vitamin D deficiency: A Global Perspectives. Arq Bras Endocrinol Metab 2006;50:640-6.

15. Bender DA, Mayes PA. Vitamins and minerals. Dalam: Murray RK, Granner DK, Mayes PA, Rodwell VW, penyunting. Harper's Illustrated Biochemistry.h.48197.

16. Holick MF. Resurrection of vitamin d deficiency and rickets. The Journal of Clinical Investigation 2006; 116:2062-72.

17. Suherman SK. Adrenokortikotropin, adrenokortikosteroid, analog-sintetik dan antagonisnya. Dalam: Ganiswarna SG, penyunting. Farmakologi dan Terapi. Edisi ke-4. Jakarta: Gaya Baru; 1998.h.482-500.

18. Bianchi ML. Glucocorticoids and bone: some general remarks and some special observations in pediatric patients. Calcified Tissue Internat 2002;70:384-90.

19. Adachi JD, Papaioannou A. In whom and how to prevent glucocorticoid-induced osteoporosis. Best Practice and Research Clinical Rheumatology 2005;19:1039-64.

20. Efthimiou J, Barnes PJ. Effects of inhaled corticosteroids on bones and growth. Eur Respir J 1998;11:1167-77.

21. Singh RF, Muskelly CC. Inhaled corticosteroidinduced bone loss and preventive strategy. JAOA 2000; 10:S14-7.

22. Garnett SP, Hogler W, Blades B, Baur La. Relation between hormones and body composition, including bone, in prepubertal children. Am J of Clin Nutrition 2004;80:966-72.

23. Sambrook PN, Jones G. Corticosteroids osteoporosis. Brit J of Rheumatol 1995;34:8-12.

24. Mazziotti G, Angeli A, Bilizekian JP, Canalis E. Glucocorticoid-Induced Oosteoporosis: an update. Trends in Endocrinology and Metabolism 2006; 17:144-9.

25. Alsufyani KA, Ortiz-Alvarez O, Cabral DA, Tucker LB. Bone mineral density in children and adolescents with systemic lupus erythematosus, juvenile dermatomyositis, 
Ayu Setyorini dkk: Pencegahan Osteoporosis dengan Suplementasi $\mathrm{Ca}^{++}$dan Vit D pada Penggunaan Kortikosteroid Jangka Panjang

and systemic vaskulitis: relationship to disease duration, cumulative corticosteroid dose, calcium intake, and exercise. J Rheumatol 2005;32:3-8.

26. Jehle PM. Steroid-Induced osteoporosis: how can it be avoided? Nephrol Dial Transplant 2003; 18:861-4.

27. Agertorft L dan Pedersen S. Bone mineral density in children with asthma receiving long-term treatment with inhaled budesonide. Am J Resp Crit Care Med 1998; 157:178-83.

28. Schlienger RG, Jick SS, Meier CR. Inhaled corticosteroids and the risk of fractures in children and adolscents. Pediatr 2004;114:469-73.

29. Sambrook PN. How to prevent steroid induced osteoporosis. Ann Rheum Dis 2005;64:176-8.

30. American college of rheumatology ad hoc committee on glucocorticoid-induced osteoporosis. recommendations for the prevention and treatment of glucocorticoidinduced osteoporosis. Arthritis and Rheumatism 2001; 44:1496-503.

31. Lovell DJ, Glass D, Ranz J, Kramer S. A randomized controlled trial of calcium supplementation to increase bone mineral density in children with juvenile rheumatoid arthritis. Arthritis \& Rheumatism 2006;54:2235-42.

32. Gulati S, Sharma RK, Gulati K, Singh U. Longitudinal follow-up of bone mineral density in children with nephrotic syndrome and the role of calcium and vitamin D supplements. Nephrol Dial Transplant 2005;20:15981603.

33. Eastell R, Reid DM, Compston J, Cooper C. A UK consensus group on management of glucocorticoidinduced osteoporosis: an update. J Internal Med 1998; 244:271-92. 